\title{
Trichoderma: A part of possible answer towards crop residue disposal
}

\section{O. Siva Devika}

Department of Soil Science and Agricultural Chemistry, Institute of Agricultural Sciences, Banaras Hindu University, Varanasi-221005 (Uttar Pradesh), India

\section{Subhadip Paul}

Department of Soil Science and Agricultural Chemistry, Institute of Agricultural Sciences, Banaras Hindu University, Varanasi-221005 (Uttar Pradesh), India

\section{Deepranjan Sarkar}

Department of Soil Science and Agricultural Chemistry, Institute of Agricultural Sciences, Banaras Hindu University, Varanasi-221005 (Uttar Pradesh), India

\section{Rahul Singh Rajput}

Department of Mycology and Plant Pathology, Institute of Agricultural Sciences, Banaras Hindu University, Varanasi, 221005 (Uttar Pradesh), India

\section{Sonam Singh}

Department of Soil Science and Agricultural Chemistry, Institute of Agricultural Sciences, Banaras Hindu University, Varanasi-221005 (Uttar Pradesh), India

Manoj Parihar

Crop Production Division, ICAR-VPKAS, Almora-263601 (Uttarakhand), India

\section{H. P. Parewa}

Department of Soil Science, College of Agriculture, Agriculture University-Jodhpur, Sumerpur Jawai Band Road, Sumerpur, Pali (Rajasthan), India

\section{Sumita Pal}

Department of Mycology and Plant Pathology, Institute of Agricultural Sciences, Banaras Hindu University, Varanasi, 221005 (Uttar Pradesh), India

\section{H. B. Singh}

Department of Mycology and Plant Pathology, Institute of Agricultural Sciences, Banaras Hindu University, Varanasi, 221005 (Uttar Pradesh), India

Amitava Rakshit*

Department of Soil Science and Agricultural Chemistry, Institute of Agricultural Sciences, Banaras Hindu University, Varanasi-221005 (Uttar Pradesh), India

*Corresponding author. E-mail: amitavar@bhu.ac.in

\begin{abstract}
India is one of the leading countries in agricultural production and generate large volume of crop residue. Increasing demand for food grains due to growing population leads to generation of crop residues. Due to lack of proper disposal mechanism of crop residue, farmers burn the residue which release greenhouse gases (GHGs) into the atmosphere, and poses great threat to environment as well as human health. The residue burning causes greater carbon emission and nutrient losses which otherwise incorporated into the soil system may substantially improve the soil biodiversity. Besides several practices of crop residue management, the most feasible method for farmers is incorporation of residue into the soil with the inoculation of microbes. In soil system the ability of microbial community in degrading organic substances is well known. In the early stages of residue decomposition simple substrates like carbohydrates are degraded by bacteria, but in later stages degradation of complex constituents viz., cellulose, lignin needs microbes which are capable of secreting enzymes like cellulase, acting on complex organic substrates. In this context, cellulolytic micro organisms like Trichoderma have the potential and emerging as an important microbial inoculants to enhance the rate of decomposition as well as alleviate the effect of residue burning.
\end{abstract}

Keywords: Agricultural production, Crop residue, Disposal, GHGs

\section{INTRODUCTION}

In India, agriculture is accounted for considerable to the economy, and wide range of crops, especially food grains are cultivated which leaves bulk of residues after harvesting of economical

\section{Article Info}

DOI:10.31018/jans.v11i2.2090

Received: May 9, 2019

Revised: June 5, 2019

Accepted: June 8, 2019

\section{How to Cite}

Devika, O.S. et al. (2019) Trichoderma: A part of possible answer towards crop residue disposal. Journal of Applied and Natural Science, 11(2): $516-523$ https:// doi.org/10.31018/ jans.v11i2.2090 part. Crop residue is the left over plant material after harvesting such as leaves, stalks and roots which is around $500 \mathrm{Mt}$ in India (GOI, 2016). Crop residue burning is the common practice among farmers due to lack of proper disposal mechanism 
Table 2. Management options for left over residue.

\begin{tabular}{|c|c|c|c|}
\hline Residue management & Residue type & Exp. Details & References \\
\hline Ethanol production & Corn & $\begin{array}{l}\text { In USA, ethanol is produced through corn residue. } \\
\text { For additional yeast nitrogen requirement protease } \\
\text { enzyme is added to the mash. }\end{array}$ & $\begin{array}{l}\text { Bothast and } \\
\text { Schlicher, } \\
2005 \text {. }\end{array}$ \\
\hline Ethanol production & Bagasse & $\begin{array}{l}\text { Ethanol is produced by oxidative delignification } \\
\text { with peroxidase and } 2 \% \mathrm{H}_{2} \mathrm{O}_{2} \text { at } 20^{\circ} \mathrm{C} \text { for } 8 \mathrm{hrs}\end{array}$ & $\begin{array}{l}\text { Sun and } \\
\text { Cheng, } 2002\end{array}$ \\
\hline $\begin{array}{l}\text { Macerating fluid by } \\
\text { solid state fermentation }\end{array}$ & Orange peel & $\begin{array}{l}\text { Rhizopus oryzae utilized orange peel under solid } \\
\text { state fermentation conditions by secreting pectin } \\
\text { lyase enzyme. Addition of } \mathrm{NH}_{4} \mathrm{NO}_{3} \text { and } \mathrm{NH}_{4} \mathrm{Cl} \\
\text { enhanced the process. }\end{array}$ & $\begin{array}{l}\text { Hamdy et } \\
\text { al., } 2005\end{array}$ \\
\hline Oyster mushroom & $\begin{array}{l}\text { Rice and } \\
\text { wheat straw }\end{array}$ & $\begin{array}{l}\text { Rice straw }(15 \%, 30 \%, 45 \%) \text { and wheat straw } \\
(20 \%, 30 \% \text { and } 40 \%) \text { as basal substrates for } \\
\text { mushroom production found cost effective method. }\end{array}$ & $\begin{array}{l}\text { Yang et al., } \\
2013\end{array}$ \\
\hline $\begin{array}{l}\text { Shiitake mushroom } \\
\text { cultivation }\end{array}$ & $\begin{array}{l}\text { Wheat bran, } \\
\text { rice bran, } \\
\text { maize powder }\end{array}$ & $\begin{array}{l}\text { In Bangladesh, mushrooms were provided with } \\
\text { different levels of wheat bran, rice bran and maize } \\
\text { powder supplementing saw dust. Wheat bran } 25 \% \\
\text { supplementation showed highest number of fruit- } \\
\text { ing bodies ( } 34.8 / 500 \mathrm{~g} \text { packet). }\end{array}$ & $\begin{array}{l}\text { Moonmoon } \\
\text { et al., } 2011\end{array}$ \\
\hline Briquette production & Rice husk & $\begin{array}{l}\text { In Brazil, factory located at Mato Grosso state } \\
\text { used rice husk as feed stock for briquette produc- } \\
\text { tion by adopting mechanical piston technology. }\end{array}$ & $\begin{array}{l}\text { Felfli et al., } \\
2011\end{array}$ \\
\hline
\end{tabular}
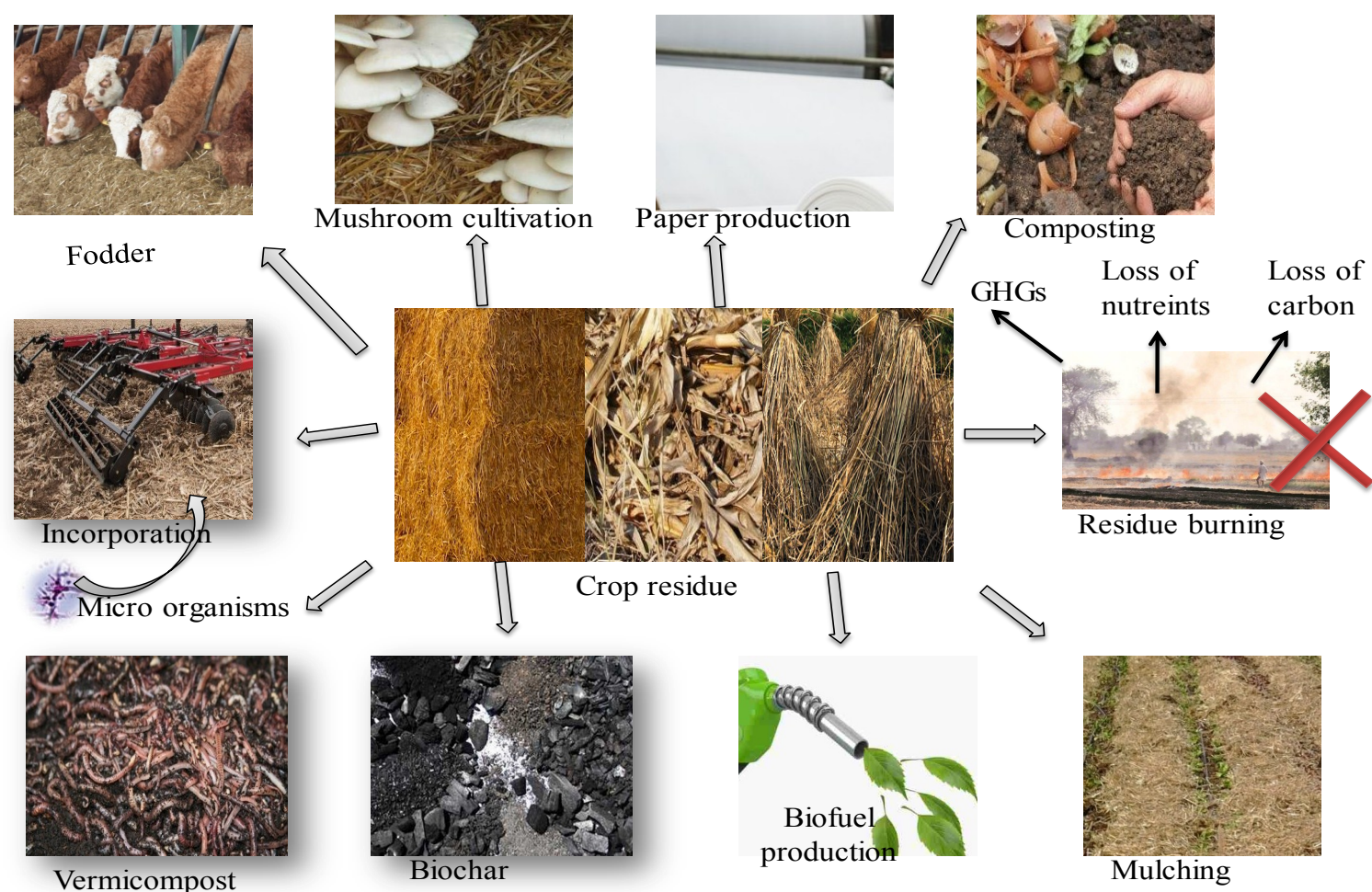

Residue burning

rop residue

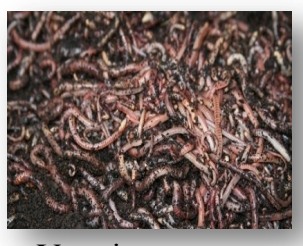

Vermicompost
Fig 2. Possible ways of utilization of crop residue.

living. Appropriate mechanism for disposal of crop residues became a considerable issue, therefore the priority is on aerobic composting through which crop residue can be transformed into organic manure by microbiological process (Sharma et al., 1999) instead of in-situ burning of residue. Rice is the most consumed food grain and is growing in large areas which generates huge quantity of residue in the form of straw, $668 \mathrm{t}$ of straw can produce 708.7 litres of bio-ethanol (Kim and Dale, 2004; Devi et al., 2017). To mitigate the complications due to residue burning, the possible approaches include crop residue as fodder, in biothermal power plants, in mushroom cultivation, production of bio-oil, as bedding material for cattle, paper production, bio-gas and incorporation of rice residue in soil, energy technologies and thermal combustion (Kumar et al., 2015; Devi et al., 2017). Some possible alternative uses (Fig. 2) of crop residue are: 
Table 3. Degradation of various organic substrates by Trichoderma spp.

\begin{tabular}{|c|c|c|c|c|}
\hline S.N. & $\begin{array}{l}\text { Microorgan- } \\
\text { isms }\end{array}$ & Substrates & Results & Authors \\
\hline 1. & $\begin{array}{l}\text { Trichoderma } \\
\text { reesei, Humi- } \\
\text { cola insolens }\end{array}$ & Paddy straw & $\begin{array}{l}\text { In an experiment conducted in Japan revealed Com- } \\
\text { bined application of TrichodermareeseiandHumicolain- } \\
\text { solensenhanced the enzyme activity. Mixture of Tricho- } \\
\text { derma and Humicola in } 75 \%: 25 \% \text { (v/v) produced } \\
79.8 \% \text { hydrolysis ration is } 10 \% \text { higher than Trichoderma } \\
\text { alone. }\end{array}$ & $\begin{array}{l}\text { Kogo et al., } \\
2017\end{array}$ \\
\hline 2 & $\begin{array}{l}\text { Trichoder- } \\
\text { mareesei }\end{array}$ & Filter paper & $\begin{array}{l}\text { Whatman no. } 1 \text { filter paper (from Maidstone, Kent, U.K) } \\
\text { was hydrolysed by cellulolytic components produced by } \\
\text { Trichodermareesei needed } 20 \mathrm{~g} \text { per one filter paper for } \\
\text { half maximal hydrolysis. }\end{array}$ & $\begin{array}{l}\text { Nidetzky et } \\
\text { al., } 1994\end{array}$ \\
\hline 3 & $\begin{array}{l}\text { Trichoder- } \\
\text { mareesei }\end{array}$ & Cellulose & $\begin{array}{l}\text { Cellobiohydrokases (CBH1 and } \mathrm{CBH} 2) \text { derived from } \\
\text { Trichodermareesei showed synergistic effect in cellu- } \\
\text { lose degradation. }\end{array}$ & $\begin{array}{l}\text { Henrissat } \\
\text { et al., } 1985\end{array}$ \\
\hline 4 & $\begin{array}{l}\text { Trichoder- } \\
\text { mareesei }\end{array}$ & Cellulose & $\begin{array}{l}\text { In an experiment conducted in Austria, the results re- } \\
\text { vealed that concentration of protease derived } \\
\text { from Trichodermareesei in extracellular fluid positively } \\
\text { correlated with the protolytic cellulose degradation prod- } \\
\text { ucts. }\end{array}$ & $\begin{array}{l}\text { Haab et al., } \\
1990\end{array}$ \\
\hline 5 & $\begin{array}{l}\text { Trichoder- } \\
\text { mareesei }\end{array}$ & Cellulose & $\begin{array}{l}\text { Transcripts of cellulase system CBH1 and EGL1 are } \\
\text { present in uninduced cells of Trichodermareesei which } \\
\text { are induced atleast } 1100 \text { fold in the presence of cellu- } \\
\text { lose (Experiment was carried out in Brazil) }\end{array}$ & $\begin{array}{l}\text { Carle- } \\
\text { Urioste et } \\
\text { al., } 1997\end{array}$ \\
\hline 6 & $\begin{array}{l}\text { Trichoder- } \\
\text { mareesei }\end{array}$ & Hard wood & $\begin{array}{l}\text { Hard wood pretreated with dilute sulphuric acid at high } \\
\text { pressure and is subjected to complete enzymatic hy- } \\
\text { drolysis resulted in production of lignacious residue. } \\
\text { During hydrolysis a significant amount of cellulase } \\
\text { found to adsorbed. }\end{array}$ & $\begin{array}{l}\text { Ooshima et } \\
\text { al., } 1990\end{array}$ \\
\hline 7 & $\begin{array}{l}\text { Trichoderma } \\
\text { spp. }\end{array}$ & Paddy straw & $\begin{array}{l}\text { In a green house experiment pots with } 6 \text { inch diameter } \\
\text { were inoculated with Trichoderma spores at } 10^{1}, 10^{2} \text {, } \\
10^{3}, 10^{4} \text { and } 10^{5} \text { per gram soil with the addition of rice } \\
\text { straw segments of } 1 \mathrm{~cm} \text {. control plot was maintained } \\
\text { without inoculating with Trichoderma. After a month } 60- \\
70 \% \text { colonization of Trichoderma on paddy straw was } \\
\text { noticed in pots with } 10^{5} \text { counts, whereas in } 10^{1} \text { to } \\
10^{3} \text { count, the observed colonization was } 20 \% \text {. The } \\
\text { decomposition of paddy straw was faster when it was } \\
\text { incorporated into the soil rather than leaving on the sur- } \\
\text { face, when moisture content was optimum and inoculat- } \\
\text { ed with more spore count. }\end{array}$ & $\begin{array}{l}\text { Cumagun } \\
\text { et al., } 2009\end{array}$ \\
\hline 8 & $\begin{array}{l}\text { Trichoder- } \\
\text { maviridae, } \\
\text { Trichoderma- } \\
\text { harzianum }\end{array}$ & Lignin & $\begin{array}{l}\text { Laccase, manganese peroxidase and lignin peroxidase } \\
\text { are produced by these fungi genera in basal medium } \\
\text { with the use of tannic acid and ABTS (2, 2'azino-bis-3- } \\
\text { ethylbenz-thiazoline- } 6 \text {-sulfonic acid) supplemented agar } \\
\text { medium. These enzymes degrade lignin via extracellu- } \\
\text { lar action and oxidation. In tannic acid agar plate Tricho- } \\
\text { dermaviridae shows highest solubilisation index and } \\
\text { zone diameter during lignin decomposition. }\end{array}$ & $\begin{array}{l}\text { Dabhi et } \\
\text { al., } 2017\end{array}$ \\
\hline 9 & $\begin{array}{l}\text { Trichoder- } \\
\text { mapseudoko } \\
\text { ningii }\end{array}$ & $\begin{array}{l}\text { Hydroxyl } \\
\text { groups pre- } \\
\text { sent in the } \\
\text { cellulose } \\
\text { structure }\end{array}$ & $\begin{array}{l}\text { Cotton fibres, treated with culture filtrate of } T \text {. pseudo- } \\
\text { koningii produces short fiber generating factor (SFGF) } \\
\text { along with breaking of hydrogen bonds in cellulose. This } \\
\text { results in rigidity loss of cellulose fibres and produces } \\
\text { short fibres (SFGF) which are more prone to get hydro- } \\
\text { lysed by the cellulase actions. }\end{array}$ & $\begin{array}{l}\text { Wang et } \\
\text { al., } 2003\end{array}$ \\
\hline 10 & $\begin{array}{l}\text { Trichoderma } \\
\text { spp. }\end{array}$ & $\begin{array}{l}\text { Sugarcane } \\
\text { trash, paddy } \\
\text { straw and } \\
\text { wheat straw }\end{array}$ & $\begin{array}{l}\text { Bio-degradation of residue like sugarcane trash, paddy } \\
\text { straw and wheat straw with the inoculation of Trichoder- } \\
\text { ma studied for } 3 \text { months under pit conditions. Paddy } \\
\text { and wheat straw has taken } 60 \text { days and sugarcane } \\
\text { trash has taken } 90 \text { days for formation of quality compost } \\
\text { with the activity of Trichoderma. At the end of the com- } \\
\text { posting } \mathrm{C}: \mathrm{N} \text { ration is decreased substantially. This } \\
\text { technique could be extended to insitu conditions. }\end{array}$ & $\begin{array}{l}\text { Sharma et } \\
\text { al., } 2012\end{array}$ \\
\hline
\end{tabular}


Biothermal power plants: One of the advisable management of crop residue is generation of electricity. At village Jalkheri, Fatehgarh Sahib, a power plant of capacity $10 \mathrm{MW}$ running based on the biomass (paddy straw) was established in 1992 and is operative since 2001 (Kumar et al., 2015; Singh, 2017).

The fuel value of crop residue per $\mathrm{Mg}$ is around $16 \times 10^{6}$ BTU (Weisz, 2004) which can be comparable to 2 barrels of diesel accounting for 18.6 $\times 10^{9} \mathrm{~J}$ or $3 \times 10^{6} \mathrm{kcal}$ of energy production (Lal, 2004). Heating value of stubbles is around $3 \times 10^{6}$ $\mathrm{kcal} / \mathrm{Mg}$ which values the energy about $50 \%$ of that of coal and comparable to diesel it is around 33\% (Larson 1979). Therefore a huge amount of biomass can be exploited for lowering the cost of electricity needed in rural household areas if used properly.

Paper manufacturing: Paper can be produced by paddy straw in combination with wheat straw in 4 to 6 ratio. Paddy straw is being used by more than $50 \%$ of pulp board mills with reference to the data furnished by PAU (Kumar et al., 2015; Singh, 2017).

Mushroom cultivation: Paddy straw can be used as bedding material for paddy straw mushroom cultivation which will assure economic and nutritional security. Wheat and rice straw are excellent bedding materials for Agaricus bisporus (white button mushroom) and Volvariella volvacea (straw mushroom) which are commonly cultivated.

Mulching: It is a process of utilizing farm left over to cover barren soil which incorporates organic matter and nutrients to the soil with the combined benefit of weed growth prevention.

Compost preparation: Crop residue can be used as cattle bedding material in cattle shed which would absorb 2-3 kg urine/ $\mathrm{kg}$ of crop residue and then heaping would be done in dung pits (Gupta et al., 2012).

Bio-fuel production: To ensure energy security, for replacement of imported crude oil and to reduce the dependency on fossil fuels, assuredly bio-fuel adoption is ecologically and commercially profitable approach. Cellulosic biomass could be utilized as feed stock for ethanol production which can either directly be used as fuel for vehicles or as gasoline additive.

Vermicompost: It is nutrient rich organic fertilizer and soil conditioner which will be prepared by the activity of earthworms to create a mixture of decomposing wastes.

Biochar: It is a fine grained, carbon rich, porous product remaining after plant biomass has been subjected to thermo-chemical conversion process (pyrolysis) at low temperature $\left(\sim 350{ }^{\circ} \mathrm{C}-600{ }^{\circ} \mathrm{C}\right)$ in an environment with little or no oxygen which would be produced with any type of residue. After conversion of plant biomass to bio-char, it constitutes recalcitrant and resistant pool of carbon, thus used as a carbon sequester in soil (Joseph and Lehmann, 2015; Bisen et al., 2017).

Residue incorporation: Instead of residue burning and removal, incorporation of residue into the soil enhances physical, chemical and biological properties of soil. Incorporation of residue avail the recycling of nutrients with a slight constraint of temporary immobilization of nutrients like nitrogen, hence additional nitrogenous fertilizer is required to mitigate high $\mathrm{C}: \mathrm{N}$ ratio of incorporated residue (Singh et al., 2005; Singh et al., 2008).

In preference to residue burning, the discussed alternative transformations of crop residue has been practically demonstrated by many authors (Table 2) as indicated.

Trichoderma may be a partial answer: In order to remove the crop residue biomass without having major impact on climate change, the residue must be returned to soil in an eco-friendly manner. The incorporation of micro biome into soil or to crop residue leftover in fields not only assures the return of sufficient residue carbon to soil but also enhances soil microbial activity in long run. Impact of these practises can lead to good nutrient recycling in soil with improved soil health. Asper crop degradation is concerned the fungi among other microbes labelled as prominent biomass utilize. It's not because of their sizes but also their predominance in wider range of soil $\mathrm{pH}$ and efficiency to assimilate a large amount of organic carbon that is present in crop leftover.

Incorporating the crop residue remained after harvest is one of the feasible and beneficial alternative with a limitation of immobilization of nutrients like nitrogen at initial stages due to high $\mathrm{C}$ : $\mathrm{N}$ ratio which could be mitigated by inoculation of fast decomposing microorganisms like Trichoderma. It is a fungi belongs to Hypocreaceae family under Ascomycota phylum, has many strains that are capable of decomposing lignocellulosic waste materials in crop fields. It degrades complex substances of organic matter viz., hemicellulose and cellulose, so that the time taken for decomposition of residue can be shortened with the advantage of nutrient mineralization and checking soil borne diseases. Generally crop residue consists of $10 \%$ dry mass of which lignin accounts for $10-25 \%$ of lingo-cellulosic materials (Bisen et al., 2017).Major portion of the residue generated i.e., paddy, wheat straw and sugarcane trash could be transformed into valuable organic compost at insitu level, thus could enhance the physical, chemical and biological properties. Besides feeding upon dead cells the fungus also kills other fungal cells, a process known as myco parasitism in soil (Deacon 2006). Trichoderma is believed to be active cellulose decomposer (Domsch and Gams, 1969). Not only cellulosic materials but Trichoderma also produce lignin peroxidise and laccasefor ligno-cellulosic material degradation which helps in lignin degra- 
dation (Dabhi et al., 2017). Thus, Trichoderma spp. helps in delignification and cellulose biodegradation in nature. The fungi have good antagonistic and bio parasitic activities as Trichoderma produces many antifungal agents that help them to regulate other phyto-pathogens (Yobo et al., 2011).

Inoculation with a mixture of cellulolytic fungi viz., Trichoderma viride and Trichoderma spiralis fasten the degradation of sugarcane trash (Rasal et al., 1988; Singh et al., 2002), whereas Trichoderma reesei reduced the time period for decomposition in mixed residue (Sharma et al., 1999; Singh et al., 2002). Trichoderma spp are highly suitable for trash recycling into quality compost, however Trichoderma harzianum is much potent in residue degradation and enhanced $\mathrm{N}, \mathrm{P}, \mathrm{K}, \mathrm{S}$ levels and decreased $\mathrm{C}: \mathrm{N}$ ratio significantly over Trichoderma viridae (Sharma et al., 2012). Benefits of inoculated Trichoderma is more noticeable when residue is incorporated into the soil than when it is on the surface, as well as at optimum moisture conditions it decomposes the residue better and Trichoderma also be associated with disease management in rice based cropping system, thus reduces the cost involved in hazardous chemicals. It degrades cellulose into simple substrates such as glucose, cellobiose and xylose. Hence Trichoder- ma can moderately deal with the complications arising due to burning of crop residues.

Trichoderma ressei uses glucose, xylose, cellobiose to meet its carbon and energy requirement (Fig.3).

Success story: In current investigation, Trichoderma is one of the possible answer for biodegradation of residue generated. Some of the experimental details are mentioned regarding decomposing of organics by Trichoderma (Table 3.)

\section{Conclusion}

Wide range of crop production in India derives huge amount of crop residue which would ultimately subjected to burning, though it has immense economic value as fodder, in bio-thermal industries, in mushroom cultivation, compost preparation and as mulch. From region to region, management aspects of residue vary depending up on socio- economic demands. Burning of residue is a noticeable reason for environmental pollution, deterioration of soil physical and chemical characteristics. To alleviate this complication, the feasible and eco-friendly management practice for crop residue disposal is its incorporation into the soil along with inoculation of cellulolytic microbes such as Trichoderma could be possible alternative for proper recycling of farm waste. Trichoderma en-

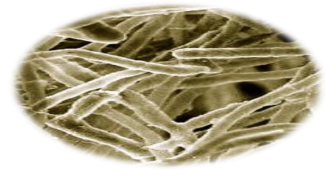

Trichoderma ressei

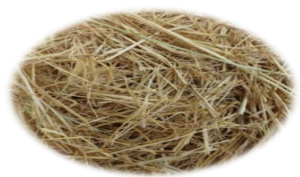

Cereal crop residue

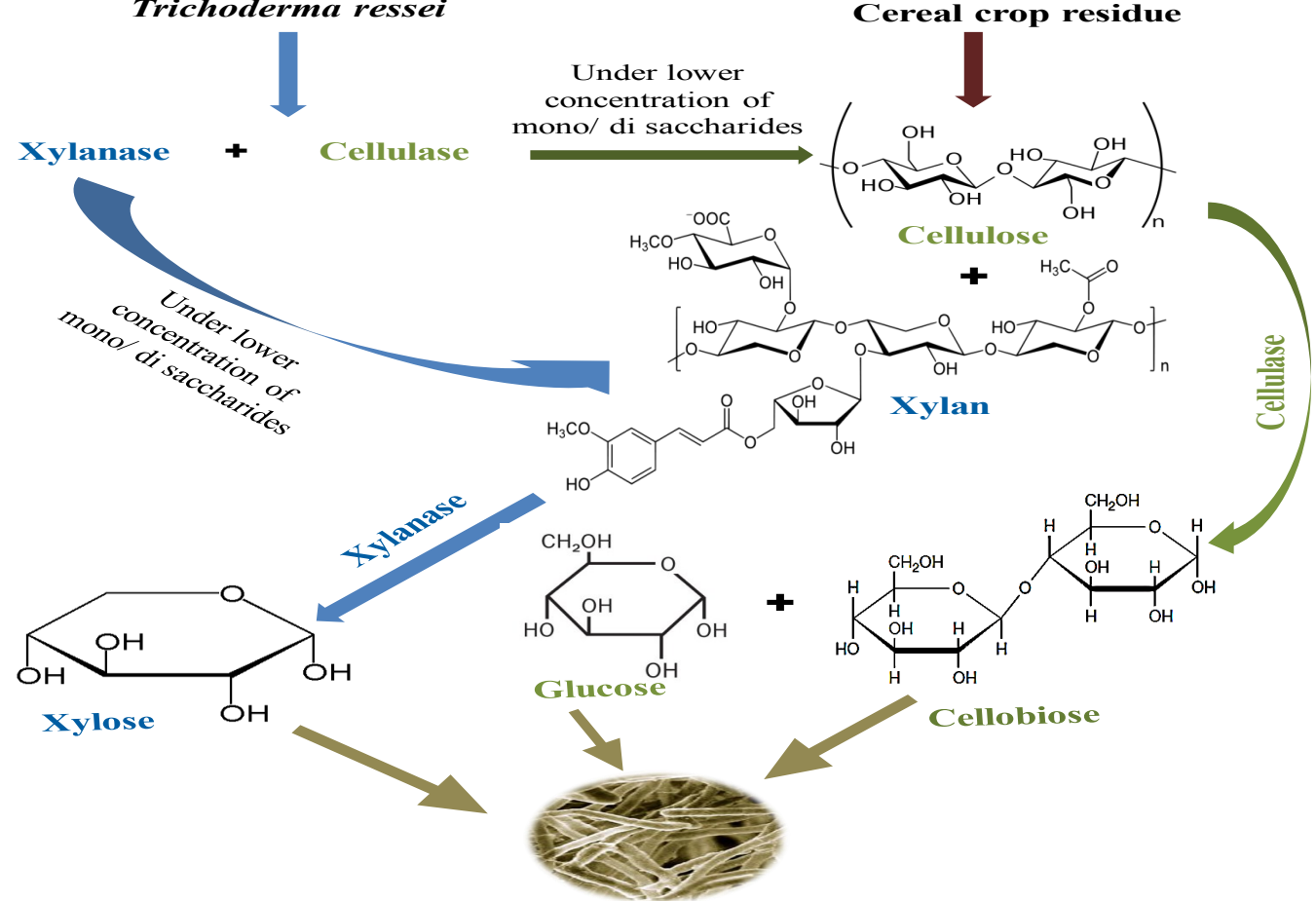

Fig. 3. Simplified diagram of T. ressei mediated crop residue degradation. 
hance decomposition rate through degrading complex compounds like cellulose, hemicelluloses and lignin of residues and improves soil health with the added advantage of saving the environment against pollution due to burning of field wastes. The major constraint in adopting this technique is inadequacy of knowledge regarding benefits of this approach among farmers. The major difficulty is acquiring farmers realization towards this complication, hence inculcating knowledge among farmers by involving multi stake holders and targeting women and youth is crucial. Environmental destruction made the world to turn towards sustainability. In the current scenario, microbial inoculants is a major concern to maintain sustainability and have incredible scope in near future.

\section{REFERENCES}

1. Bisen, N., and Rahangdale, C.P. (2017). Crop residues management option for sustainable soil health in rice-wheat system: A review. Int. J.Comput. Syst. 5:1038-1042

2. Bothast R. J. and Schlicher, M. A. (2005). Biotechnological processes for conversion of corn into ethanol. Applied Microbiology and Biotechnology. 67, 19-25

3. Carle-Urioste J.C., Escobar-Vera J, El-Gogary, S., Henrique-Silva, F., Torigoi, E., Crivellaro, O., Herrera -Estrella, A. and El-Dorry, H. (1997). Cellulase induction in Trichoderma reesei by cellulose requires its own basal expression. J Biol. Chem. 272:1016910174

4. Cumagun, C.J., Manalo, J.O., Salcedo-Bacalangco. N.A. and llag, L.L. (2009). Cellulose decomposing ability of Trichoderma in relation to their saprophytic survival. Arch of Phytopathol and Plant Prot. 42:698-704. https://doi.org/10.1080/03 235400 701492731

5. Dabhi, B.K., Vyas, R.V. and Shelat, H.N. (2017).Biodegradation of lignin by fungal cultures. J. of Pharmacognosy and Phytochem. 6:1840-1842

6. Devi, S., Gupta, C., Jat, S.L. and Parmar, M.S. (2017). Crop residue recycling for economic and environmental sustainability: The case of India. Open Agric.2:486-94. DOI: https://doi.org/10.1515/opag2017-0053

7. Domsch, K.H. and Cams, W. (1969). Variability and potential of a soil fungus population to decompose pectin, xylan and carboxy-methylcellulose. Soil Biol Biorhem.1:29-36. https://doi.org/10.1016/0038-0717 (69) $90031-5$

8. Felfli, F.F., Rocha, J.D., Filippetto, D., Luengo, C.A. and Pippo, W.A. (2011). Biomass briquetting and its perspectives in Brazil. Biomass and Bioenergy. 35 (1), 236-242.https://doi.org/10.1016/j.biombioe.2 010. 08.011

9. GOI, Annual Report (2016). Ministry of New and Renewable Energy, New Delhi. (http:// mnre.gov.in).http://www.erewise.com/current-affairs/ biomass-resources in india_art52cbbb9bcd5d f.mht ml\#. Vd9atPmqqko

10.Gupta H, Dadlani M. (2012). Crop residues management with conservation agriculture: Potential, constraints and policy needs.

11.Gupta, R.K., Naresh, R.K., Hobbs, P.R., Jiaguo, Z.,
Ladha, J.K. (2003). Sustainability of post-green revolution agriculture: the rice-wheat cropping systems of the Indo-Gangetic Plains and China. Improving the productivity and sustainability of rice-wheat systems: Issues and impacts, (improvingthepro), 1-25.

12. Haab, D., Hagspiel, K., Szakmary, K. and Kubicek, C.P. (1990). Formation of the extracellular proteases from Trichoderma reesei QM 9414 involved in cellulase degradation. J Biotechnol. 16:187-198. https:// doi.org/10.1016/0168-1656(90)90035-A

13. Hamdy, H.S. (2005). Purification and characterization of pectin lyase produced by Rhizopus oryzae grown on orange peels. Annals of Microbiology, 55(3), 205.

14. Hassanein, N.M. (2012). Biopotential of some Trichoderma spp. against cotton root rot pathogens and profiles of some of their metabolites. African Journal of Microbiology Research. 6(23), 4878-4890. DOI: 10.5897/AJMR11.1088

15. Henrissat,. B, Driguez, H., Viet, C. and Schülein, M. (1985). Synergism of cellulases from Trichoderma reesei in the degradation of cellulose. Biotechnology 3:722. https://doi.org/10.1002/bit.260360503

16.Jain, N., Bhatia, A. and Pathak, H. (2014). Emission of air pollutants from crop residue burning in India. Aerosol and Air Qual Res. 14:422-430. doi: 10.4209/ aaqr.2013.01.0031

17.Joseph, S. and Lehmann, J. (2015). Biochar for environmental management: an introduction. In: Biochar for environmental management. Routledge, pp 33-46

18.Keswani, C., Singh, S.P. and Singh, H.B. (2013). A superstar in biocontrol enterprise: Trichoderma spp. Biotech Today. 3(2), 27-30. DOI: 10.5958/23220996.2014.00005.2

19.Kim, S. and Dale, B.E. (2003). Cumulative energy and global warming impact from the production of biomass for biobased products. J Ind Ecol. 7:147162. https://doi.org/10.1162/108819803323059442

20.Kogo, T., Yoshida, Y., Koganei, K., Matsumoto, H., Watanabe, T., Ogihara, J.and Kasumi, T. (2017). Production of rice straw hydrolysis enzymes by the fungi Trichoderma reesei and Humicolainsolens using rice straw as a carbon source. BioresourTechnol. 233:67-73.https://doi.org/10.1016/j.biortech.20 17.01 .075

21.Kumar P., Kumar, S. and Joshi, L. (2015). Socioeconomic and Environmental Implications of Agricultural Residue Burning: A Case Study of Punjab, India. Springer Open. DOI 10.1007/978-81-322-2014-5

22.Lal, R. (2004). World crop residues production and implications of its use as a biofuel. Environ Int. 31:575-584. https://doi.org/10.1016/j.envint. 20 04.09 .005

23.Larson, W.E. (1979). Crop residue: energy production on erosion control. J Soil Water Conservation. 34:74-76

24.Moonmoon, M., Shelly, N.J., Khan, M.A., Uddin, M.N., Hossain, K., Tania, M. and Ahmed, S. (2011). Effects of different levels of wheat bran, rice bran and maize powder supplementation with saw dust on the production of shiitake mushroom (Lentinus edodes (Berk.) Singer). Saudi journal of biological sciences. 18(4), 323-328. https://doi.org/10.1016/j.sjbs.20 10.12.008

25.MOSPI (2013-14). Ministry of Statistics and Program Implementation, http://www.mospi.gov.in/announc emen ts /asi-2013-14-vol-i.

26.Nidetzky, B., Steiner, W., Hayn, M. and Claeyssens, 
M. (1994). Cellulose hydrolysis by the cellulases from Trichoderma reesei: a new model for synergistic interaction. Biochem. J. 298:705-710. DOI: 10.1042/ bj2980705

27. Ooshima, H., Burns, D.S. and Converse, A.O. (1990). Adsorption of cellulase from Trichoderma reesei on cellulose and lignacious residue in wood pretreated by dilute sulfuric acid with explosive decompression. Biotechnol Bioeng. 36:446-452.

28.Rasal, P.H., Kalbhor, H.B., Shingte, V.V. and Patil, P.L. (1998). Development of technology for rapid composting and enrichment. Biofertilizers, Potentialities and Problems. pp255-258

29.Sarkar, A., Yadav, R.L., Gangwar, B. and Bhatia, P.C. (1999). Crop residues in India. Technical Bulletin, Project Directorate for Cropping System Research, Modipuram.

30.Sharma, B.L., Singh, S.P. and Sharma, M.L. (2012). Bio-degradation of crop residues by Trichoderma species vis-à vis nutrient quality of the prepared compost. Sugar Tech. 14:174-180

31.Sharma, S., Mathur, R.C. and Vasudevan, P. (1999). Composting silkworm culture waste. Compost Sci. Util. 7:74-81. https://doi.org/10.10 80/10 $656 \quad 57$ X.1999.10701967

32.Singh, A. and Sharma, S. (2002).Composting of a crop residue through treatment with microorganisms and subsequent vermicomposting. Bioresour Technol. 85:107-111. https://doi.org/10.1016/S0960-8524 (02)00095-0

33.Singh, V.K. (2017). Alternative utilization of crop resi- dues: Tackling negative impacts of burning in India.

34.Singh, Y., Singh, B. and Timsina, J. (2005). Crop residue management for nutrient cycling and improving soil productivity in rice-based cropping systems in the tropics. Advances in Agronomy. 85:269-407

35.Sun, Y. and Cheng, J. (2002). Hydrolysis of lignocelIulosic materials for ethanol production: a review. Bioresource Technology. 83, 1-11. https:// doi.org/10.1016/S0960-8524(01)00212-7

36.Wang, L.S., Liu, J., Zhang, Y.Z., Zhao, Y. and Gao, P.J. (2003). Comparison of domains function between cellobiohydrolase I and endoglucanase I from Trichoderma pseudokoningii S-38 by limited proteolysis. Journal of Molecular Catalysis B: Enzymatic, 24, 27-38.

37.Weisz, P.B. (2004). Basic choices and constraints on long-term energy supplies. Phys Today. 57:47-52

38.Yang, W., Guo, F. and Wan, Z. (2013). Yield and size of oyster mushroom grown on rice/wheat straw basal substrate supplemented with cotton seed hull. Saudi Journal of BiologicalSsciences. 20(4), 333 -338. https://doi.org/10.1016/j.sjbs.2013.02.006

39. Yevich, R. and Logan, J.A. (2003). An assessment of biofuel use and burning of agricultural waste in the developing world. Global Biogeochemical Cycles. 17 (4). Doi:10.1029/2002GB001952

40.Yobo, K.S., Laing, M.D. and Hunter, C.H. (2011). Effects of single and combined inoculations of selected Trichoderma and Bacillus isolates on growth of dry bean and biological control of Rhizoctonia solani damping-off. Afr J Biotechnol. 10:8746-8756 